\title{
Microgreens Production with Low Potassium Content for Patients with Impaired Kidney Function
}

\author{
Massimiliano Renna ${ }^{1, *}$, Maria Castellino ${ }^{2}$, Beniamino Leoni ${ }^{1}$, Vito Michele Paradiso ${ }^{2}$ (D) and \\ Pietro Santamaria ${ }^{1}$ \\ 1 Department of Agricultural and Environmental Science, University of Bari Aldo Moro, \\ Via Amendola 165/A, 70126 Bari, Italy; beniamino.leoni@uniba.it (B.L.); pietro.santamaria@uniba.it (P.S.) \\ 2 Department of Soil, Plant and Food Science, University of Bari Aldo Moro, Via Amendola 165/A, \\ 70126 Bari, Italy; maria.castellino@uniba.it (M.C.); vitomichele.paradiso@uniba.it (V.M.P.) \\ * Correspondence: massimiliano.renna@uniba.it; Tel.: +39-080-5443098
}

Received: 11 April 2018; Accepted: 24 May 2018; Published: 26 May 2018

\begin{abstract}
Chronic kidney disease represents a global problem together with other so-called 'lifestyle-related diseases'. Unlike the healthy population, for the patients with impaired kidney function, it is of course prudent to recommend a restriction of high-potassium foods. Thus, it is suggested to limit the consumption of vegetables, because they generally contain high concentrations of potassium. At the same time, a lower consumption of vegetables reduces the intake of healthy compounds such as vitamins, fibers, and antioxidants, which also reduces the vegetables' potential benefit in chronic kidney disease patients. Microgreens are an emerging class of specialty crop that represent a nutritious and refined food. In this study, for the first time, some chicory (local variety 'Molfetta' and cultivar 'Italico a costa rossa') and lettuce (cultivar 'Bionda da taglio') genotypes were grown using a hydroponic system with different potassium (K) levels $\left(0,29.1,58.4\right.$, and $\left.117 \mathrm{mg} \mathrm{L}^{-1}\right)$ in order to produce microgreens with a low potassium content. The crop performances, cations content, proximate composition, and antioxidant activity were analyzed. Independent of the genotype, the $\mathrm{K}$ content in the microgreens was successfully reduced using a nutrient solution (NS), without K or with $29.1 \mathrm{mg} \mathrm{K} \mathrm{L}^{-1}$, which supplied between 103 and $129 \mathrm{mg}$ of $\mathrm{K} 100 \mathrm{~g}^{-1} \mathrm{FW}$ (about 7.7-8.6\% of the $\mathrm{K}$ daily intake that was recommended for the patients that were affected by chronic kidney disease). Whereas, $100 \mathrm{~g}$ of microgreens that were grown by using an NS with 58.4 or $117 \mathrm{mg} \mathrm{K} \mathrm{L}^{-1}$ supply between 225 and $250 \mathrm{mg}$ of $\mathrm{K}$ (about $15.8-16.5 \%$ of the $\mathrm{K}$ daily intake recommended for patients affected by chronic kidney disease). No differences were observed in terms of the shoot height, dry matter, proximate composition, and visual quality. A slightly lower yield was observed using an NS with a K concentration $<58.4 \mathrm{mg} \mathrm{L}^{-1}$. These results suggest that by using an NS without $\mathrm{K}$ or with low $\mathrm{K}$ concentrations, it is possible to obtain a useful reduction of $\mathrm{K}$ in microgreens, without negatively affecting the quality. Unlike conventional vegetables, the microgreens that were produced in the present study could reduce the potassium intake in patients with impaired kidney function who were accustomed to eating vegetable-based dishes.
\end{abstract}

Keywords: antioxidant activity; Cichorium intybus L.; hydroponic system; Lactuca sativa L.; potassium intake; proximate composition

\section{Introduction}

For the human body, potassium $(\mathrm{K})$ is an essential nutrient that is involved in fluid, acid, and electrolyte balance and it is required for normal cellular function, such as DNA and protein synthesis [1]. It is well known that $\mathrm{K}$ can modulate blood pressure, and that an increasing dietary $\mathrm{K}$ intake is associated with lower blood pressure. For this reason, the World Health Organization [2] 
recommends a $\mathrm{K}$ intake of at least $3510 \mathrm{mg}$ day $^{-1}$, to decrease the risk of cardiovascular diseases. Based on the estimates of the current $\mathrm{K}$ intakes in Europe (up to 5-6 $\mathrm{g}^{\text {day }}{ }^{-1}$ in adults), the risk of adverse effects from the $\mathrm{K}$ intake from food is considered to be low for the generally healthy population [3]. Nevertheless, certain groups, particularly those with impaired an kidney excretion of potassium, are sensitive to the adverse effects of increasing the $\mathrm{K}$ intake on heart function that is associated with increases in the plasma potassium. These groups firstly include subjects with chronic kidney disease, one of the so-called 'lifestyle-related diseases', together with hyperlipidemia, hypertension, and diabetes [4]. Chronic kidney disease represents a global problem, and it is estimated that by 2020, the number of dialysis patients will be around 3.8 million [5]. Unlike the healthy population, the $\mathrm{K}$ intake for the patients that are affected by chronic kidney disease is often restricted to $1500 \mathrm{mg} \mathrm{day}^{-1}$ [6]. In addition to these subjects, patients that also use pharmaceuticals that affect the kidney excretion of potassium, such as mineralocorticoid receptor antagonists, should be considered. Therefore, for all of these patients, the $\mathrm{K}$ intake must be restricted in order to avoid adverse effects on heart function as a result of disturbances in the plasma potassium concentration, most commonly known as hyperkalemia [7]. It is important to highlight that some investigators have begun to question the need to severely restrict potassium in chronic kidney disease patients, given the relative lack of published studies that support this strategy. However, in the absence of empirical evidence and conclusive data, it is of course prudent to continue to recommend a restriction of high-potassium foods for patients with impaired kidney function [8].

Since vegetables contain high concentrations of potassium $[9,10]$, it is suggested that the patients with impaired kidney function do not take raw vegetables, rather, they should be soaked in water and boiled in order to reduce the K content through leaching [11]. Nevertheless, a K reduction by these cooking methods can be considered limited, while other important minerals and hydrophilic vitamins could be significantly lost [12-14]. In addition, it should be considered that people are also accustomed to eating raw vegetables, which makes it difficult to propose some vegetable-based dishes for patients with impaired kidney function. For example, eating raw salads is desirable for the dialysis patients and all of the subjects with an impaired renal excretion of potassium. Therefore, a dietary intake of vegetables that contains a lower $K$ than usual could be a very useful health prevention method for the patients with impaired kidney function, which limits a decrease in the quality of life. In this context, the production of vegetables with low $\mathrm{K}$ content could be of great interest for research, considering that limited information is being reported in the literature [15-17].

Microgreens are an emerging class of specialty crop that can be considered as young and tender edible seedlings that are produced from the seeds of vegetables, herbs, or grains, including wild species. Depending on the species and growing conditions, microgreens are generally harvested 7-21 days after germination, when the cotyledon leaves have fully developed, and the first true leaves have emerged [18]. Microgreens can be used to enhance salads or as edible garnishes to embellish a wide variety of other dishes. Moreover, Renna et al. [19] has developed a new culinary concept that consists of considering self-produced microgreens as basic ingredients for the preparation of sweet and savory dishes, with interesting quality traits. At the same time, it has been reported that microgreens can provide higher amounts of phytonutrients (ascorbic acid, $\beta$-carotene, $\alpha$-tocopherol, and phylloquinone) and minerals ( $\mathrm{Ca}, \mathrm{Mg}, \mathrm{Fe}, \mathrm{Mn}, \mathrm{Zn}, \mathrm{Se}$, and $\mathrm{Mo}$ ), compared with their mature-leaf counterparts [18]. Thanks to their distinctive peculiarities, microgreens represent a rich food source for particularly demanding categories of consumers, like vegetarians and vegans, who can diversify and enrich their diet using a large variety of microgreens that are available. Moreover, as the microgreens are usually consumed raw, they can also satisfy the specific needs of the so-called 'raw foodists' [20]. Lastly, the chance of growing microgreens in a very simple way, even in very little spaces, means that microgreens garner immense potential for adapting leafy vegetable production to a micro-scale and for improving nutritional value in the human diet $[18,21]$. This allows microgreens to be considered as ideal candidates for astronaut's functional salads and, therefore, as a component of space-life support systems [22]. 
To the best of our knowledge, the literature absolutely lacks information on microgreens production, without or with a low potassium content. Therefore, starting from the above-mentioned considerations, the aims of the present study are as follows: (i) to investigate on the impact of reduced potassium concentrations in nutrient solution on the $\mathrm{K}$ content of microgreens and (ii) to assess the yield and nutritional quality of the microgreens that are grown using nutrient solutions with different potassium concentrations.

\section{Materials and Methods}

\subsection{Experimental Conditions}

Two experiments were conducted using a hydroponic system during the spring of 2017 in a green-house located at the University of Bari Aldo Moro ( $41^{\circ} 06^{\prime} \mathrm{N}, 16^{\circ} 52^{\prime} \mathrm{E}$; Southern Italy). The first experiment was carried out from 5 to 18 April, while the second experiment was carried out from 20 April to 3 May. The experimental factors were (i) three genotypes (G) and (ii) three levels of $K$ in the nutrient solution (NS).

Two different $\mathrm{G}$ of chicory (Cichorium intybus L.) and one $\mathrm{G}$ of lettuce (Lactuca sativa L. Group crispa) were grown. The chicory seeds of the local variety 'Molfetta' (CM-a stem chicory type) and cultivar 'Italico a costa rossa' (CI-a leafy chicory type) were used, while a cultivar 'Bionda da taglio' (LB) was used for the lettuce seeds. All of the seeds were purchased from the Riccardo Larosa Company (Andria, Italy). The seeds were of a high quality, with a 95\% germination at a constant temperature of $20^{\circ} \mathrm{C}$. A hydroponic tray system for the microgreens culture was created using polyethylene terephthalate fiber pads $\left(50 \mathrm{~cm} \times 24 \mathrm{~cm} \times 0.89 \mathrm{~cm}\right.$; Sure to Grow ${ }^{\circledR}$; Sure to Grow, Beachwood, $\mathrm{OH}$, USA) as a growing medium that was placed on a $2.7 \mathrm{~m}^{2}(1 \times 2.7 \mathrm{~m})$ aluminum bench. The seeds were uniformly broadcasted on the surface of the growing media using a seeding density of four seeds $\mathrm{cm}^{-2}$. The sown fiber pads were irrigated manually using a water-nozzle and were covered with a black polyethylene film until the germination was complete.

The seedlings were fertigated by subirrigation with NS, having three levels of K. For the first experiment, the $\mathrm{K}$ levels were $0,58.4$ and $117.0 \mathrm{mg} \mathrm{L}^{-1}$, while for the second experiment, the $\mathrm{K}$ levels were $0,29.1$ and $58.4 \mathrm{mg} \mathrm{L}^{-1}$. A split-plot design with three replications was used. In all of the cases, the NS were prepared with pre-collected raining water containing $\left(\mathrm{mg} \mathrm{L}^{-1}\right)$ the following: 119 nitrogen, 16 phosphorus, 24 magnesium, 116 calcium, 54 sulfur, 1.12 iron, 0.27 manganese, 0.13 zinc, 0.27 boron, 0.03 copper, and 0.01 molybdenum, which resulted in an EC of $1.8 \mathrm{dS} \mathrm{m}^{-1}$ and $\mathrm{pH} 6.3$. The $\mathrm{NO}_{3}-\mathrm{N}: \mathrm{NH}_{4}-\mathrm{N}$ at a percentage ratio of $84: 16$ was used for the nitrogen source. The NS was delivered on the bench by a drip tape line with pressure-compensated drippers (each with a delivery rate of $7.0 \mathrm{~L} \mathrm{~h}^{-1}$ ). The drainage was collected in a reservoir tank at the base of the bench, but it was not reused (open cycle management).

The values of the average relative humidity, average mean, minimum and maximum air temperatures, and photosynthetically active radiation inside the greenhouse, over the first and second experiment, are reported in Figure 1.

\subsection{Harvesting, Yield Assessment, and Samples Preparation}

At the first appearance of the first true-leaves (Figure 2), the shoot height was measured, after which the microgreens were harvested by cutting the seedling just above the surface of the growing media with a knife. The harvested microgreens were weighed to determine the shoot fresh weight (FW) per unit area. The sub-samples were dried to a constant weight in a forced-draught oven at $65{ }^{\circ} \mathrm{C}$ and were weighed so as to determine their dry matter (DM) concentration. The oven dried samples were used for cation contents determination. The other sub-samples were freeze-dried (ScanVac CoolSafe 55-9 Pro; LaboGene ApS, Lynge, Denmark) and then used for proximate analysis and antioxidant activity determination. 


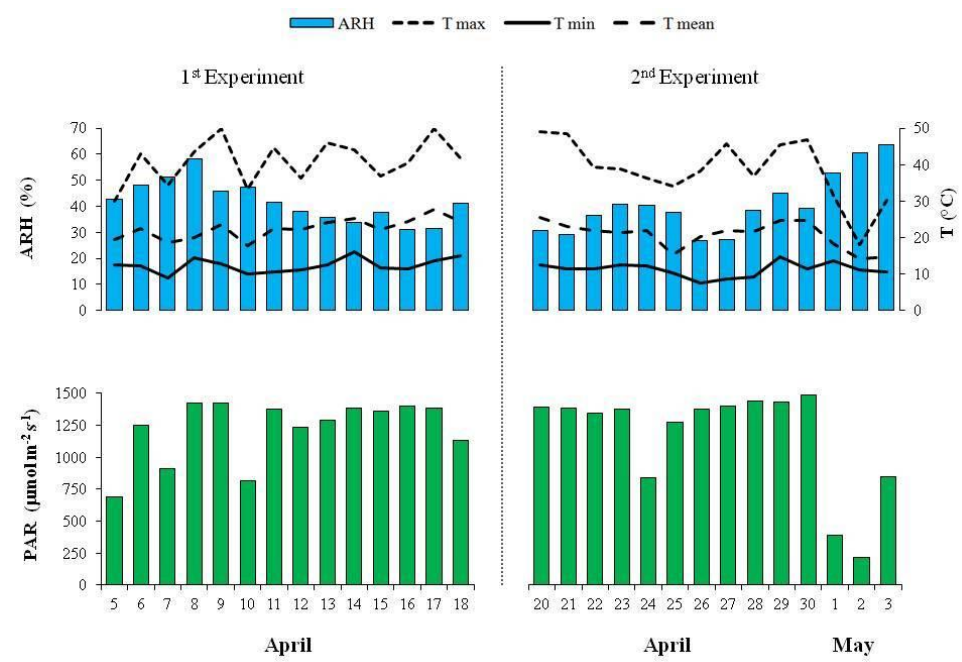

Figure 1. Average relative humidity (ARH), average mean, minimum (min) and maximum (max) air temperatures (broken lines), and photosynthetically active radiation (PAR) inside the greenhouse over the first and second experiment.

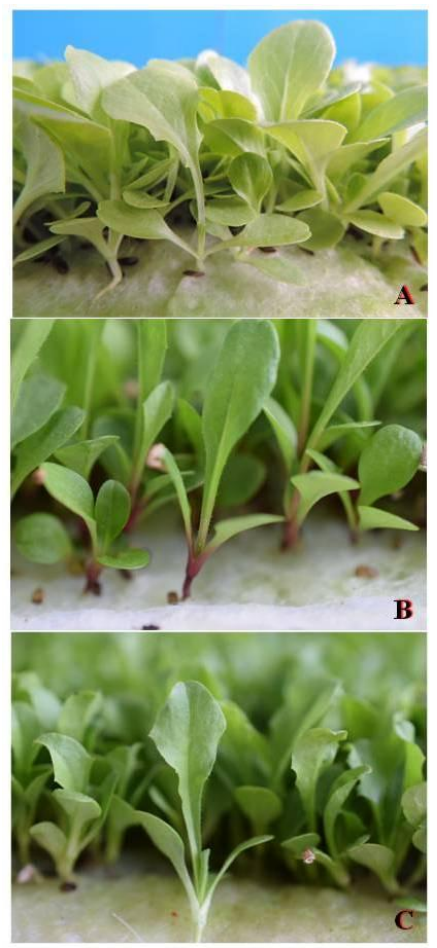

Figure 2. Harvesting stage (first true-leaves) of microgreens grown with $0 \mathrm{mg} \mathrm{K} \mathrm{L}^{-1}$ in the nutrient solution, namely: (A) lettuce cultivar 'Bionda da taglio'; (B) chicory cultivar 'Italico a costa rossa'; and $(\mathrm{C})$ chicory local variety 'Molfetta'.

\subsection{Chemical Analysis}

The proximate analysis of the samples was carried out as follows: ashes were determined by muffle furnace according to AOAC method 923.03 [23]; proteins content $(\mathrm{N} \times 6.25)$ was determined by Kjeldahl nitrogen, according to the AOAC method 955.04 [23]; fat content was determined by Soxhlet extraction, according to the AOAC method 920.39 [23]; dietary fiber content was determined by the enzymatic-gravimetric procedure, according to the AOAC method 991.43 [23]; and total carbohydrates were calculated by the difference of protein, lipid, and ash on the dry matter basis. 
The effect of different $\mathrm{K}$ supplementations on the antioxidant activity of microgreens by electron transfer mechanisms was evaluated using the 2,2-diphenyl-1-picrylhydrazyl (DPPH) stable radical scavenging capacity test, according to Difonzo et al. [24]. The freeze dried samples $(0.1 \mathrm{~g})$ were extracted with $5 \mathrm{~mL}$ methanol:water (80:20) for two hours, in tubes that were covered with aluminum foil. The extracts were then centrifuged for $15 \mathrm{~min}$ at $15,000 \mathrm{~g}$ and $24^{\circ} \mathrm{C}$. The supernatant was recovered and filtered with polytetrafluoroethylene (PTFE) septa $(0.45 \mu \mathrm{m})$. The extracts $(50 \mu \mathrm{L})$ were added to $950 \mu \mathrm{L}$ of $0.08 \mathrm{mM}$ DPPH in methanol. The mixture was shaken and left at room temperature in the dark for $30 \mathrm{~min}$. The decrease of the absorbance at $517 \mathrm{~nm}$ was measured using a Cary 60 Agilent spectrophotometer (Agilent Technologies, Milan, Italy). The results were expressed in $\mu$ mol Trolox equivalents (TE) $100 \mathrm{~g}^{-1} \mathrm{FW}$. Each sample was analyzed in triplicate.

For the inorganic ion content, an ion exchange chromatography (Dionex DX120; Dionex Corporation, Sunnyvale, CA, USA) with a conductivity detector was performed, as reported by D'Imperio et al. [25]. The cation contents $\left(\mathrm{Na}^{+}, \mathrm{K}^{+}, \mathrm{Mg}^{2+}\right.$, and $\left.\mathrm{Ca}^{2+}\right)$ were determined in $1 \mathrm{~g}$ of dried sample, using an IonPac CG12A guard column and an IonPac CS12A analytical column (Dionex Corporation).

\subsection{Statistical Analysis}

The data were analyzed by a two-way analysis of variance (ANOVA), using the general linear model procedure of SAS software (SAS Version 9.1, SAS Institute, Cary, NC, USA). All of the means were compared using Student-Newman-Keuls (SNK) test at $p=0.05$.

\section{Results}

\subsection{Crop Performance}

In the first experiment, the CM that was grown with 58.4 and $117 \mathrm{mg} \mathrm{K} \mathrm{L}^{-1}$ showed the highest yield, about $72 \%$ higher on average than that of all of the genotypes that were grown with $0 \mathrm{mg} \mathrm{K} \mathrm{L}^{-1}$ (Figure 3A).

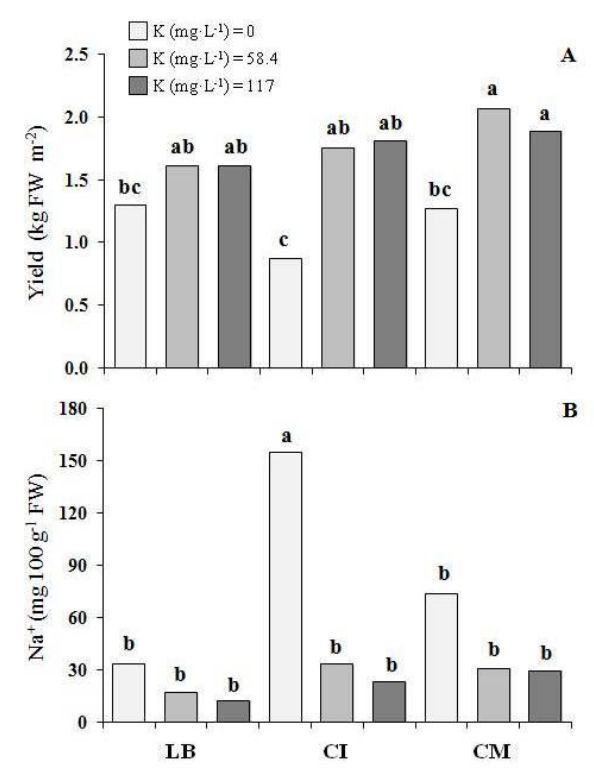

Figure 3. (A) Yield and (B) $\mathrm{Na}^{+}$content of three genotype of microgreens grown with three potassium levels (first experiment). LB-lettuce 'Bionda da taglio'; CI—chicory 'Italico a foglia rossa'; CM—chicory 'Molfetta'. For each histogram, the same lowercase letters indicate that the mean values are not significantly different $(p=0.05)$.

At the same time, the K level in the NS did not affect the yield for LB, while for the CI that was grown with 58.4 and $117 \mathrm{mg} \mathrm{K} \mathrm{L}^{-1}$, the yield increased by $105 \%$ with respect to the $0 \mathrm{~K}$ level 
(Figure 3A). No differences were observed in terms of the shoot height $(4.1 \mathrm{~cm}$, on average) and dry

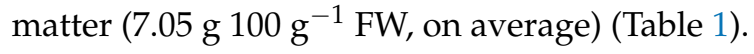

In the second experiment, the highest yield was observed for the CM followed by the $\mathrm{CI}$ and $\mathrm{LB}$, while $58.4 \mathrm{mg} \mathrm{K} \mathrm{L}^{-1}$ obtained a yield $22 \%$ higher, compared with the other levels of $\mathrm{K}$ in the NS (Table 2). With regards to the shoot height, the CM and CI showed the highest values, while no

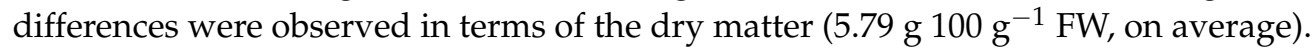

Table 1. Effects of genotype and potassium on yield, shoot height, dry matter, and inorganic cations of microgreens (first experiment).

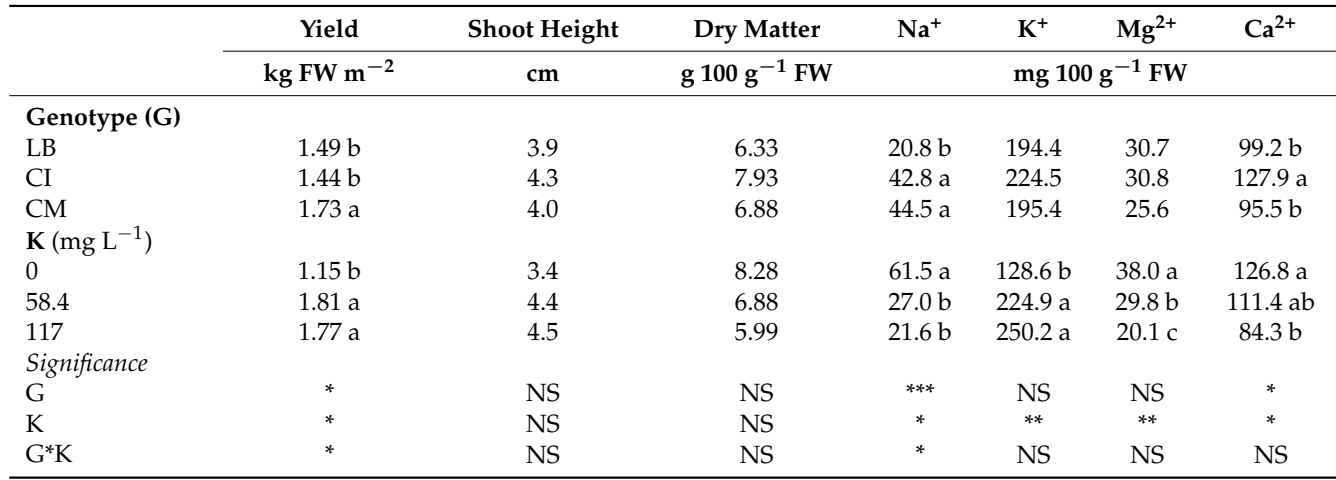

LB-lettuce 'Bionda da taglio'; CI-chicory 'Italico a costa rossa'; CM-chicory 'Molfetta'. Within the same main effect and for each parameter, the same lowercase letters in the same column indicate that the mean values are not significantly different $(p=0.05) . \mathrm{G} \times \mathrm{K}$ significant interactions are reported in Figure 3. Significance: ${ }^{* *},{ }^{* *}$, and * for $p \leq 0.001, p \leq 0.01$, and $p \leq 0.05$, respectively; NS-not significant.

Table 2. Effects of genotype and potassium on yield, shoot height, dry matter and inorganic cations of microgreens (second experiment).

\begin{tabular}{|c|c|c|c|c|c|c|c|}
\hline & Yield & Shoot Height & Dry Matter & $\mathrm{Na}^{+}$ & $\mathbf{K}^{+}$ & $\mathrm{Mg}^{2+}$ & $\mathrm{Ca}^{2+}$ \\
\hline & kg FW m ${ }^{-2}$ & $\mathrm{~cm}$ & $\mathrm{~g} 100 \mathrm{~g}^{-1} \mathrm{FW}$ & \multicolumn{4}{|c|}{$\mathrm{mg} 100 \mathrm{~g}^{-1} \mathrm{FW}$} \\
\hline \multicolumn{8}{|c|}{ Genotype (G) } \\
\hline LB & $1.83 \mathrm{c}$ & $4.6 \mathrm{~b}$ & 5.85 & $13.5 \mathrm{~b}$ & 154.4 & 31.6 & 101.1 \\
\hline $\mathrm{CI}$ & $2.27 \mathrm{~b}$ & $5.1 \mathrm{a}$ & 6.24 & $31.1 \mathrm{a}$ & 168.3 & 29.7 & 110.4 \\
\hline $\mathrm{CM}$ & $2.53 \mathrm{a}$ & $5.0 \mathrm{a}$ & 5.29 & $32.1 \mathrm{a}$ & 157.4 & 28.7 & 88.1 \\
\hline \multicolumn{8}{|c|}{$\mathbf{K}\left(\mathrm{mg} \mathrm{L}^{-1}\right)$} \\
\hline 0 & $2.08 \mathrm{~b}$ & 4.5 & 6.01 & 32.5 & $103.2 \mathrm{~b}$ & 33.2 & 107.3 \\
\hline 29.1 & $2.04 \mathrm{~b}$ & 4.9 & 5.06 & 20.6 & $129.7 \mathrm{~b}$ & 26.2 & 90.4 \\
\hline 58.4 & $2.52 \mathrm{a}$ & 5.3 & 6.30 & 23.7 & $247.1 \mathrm{a}$ & 30.6 & 101.8 \\
\hline \multicolumn{8}{|c|}{ Significance } \\
\hline G & $* * *$ & $* *$ & NS & $* * *$ & NS & NS & NS \\
\hline K & $*$ & NS & NS & NS & $*$ & NS & NS \\
\hline$G^{*} K$ & NS & NS & NS & NS & NS & NS & NS \\
\hline
\end{tabular}

LB-lettuce 'Bionda da taglio'; CI—chicory 'Italico a costa rossa'; CM-chicory 'Molfetta'. Within the same main effect and for each parameter, the same lowercase letters in the same column indicate that the mean values are not significantly different $(p=0.05)$. Significance: ${ }^{* * * * *}$, and ${ }^{*}$ for $p \leq 0.001, p \leq 0.01$, and $p \leq 0.05$, respectively; NS-not significant.

\subsection{Cation Contents}

In the first experiment, the highest sodium content was found in the $\mathrm{CI}$ that was grown with $0 \mathrm{mg} \mathrm{K} \mathrm{L}{ }^{-1}$ (Figure 3B and Table 1). No differences in the potassium content were found between the three $G$, while with 0 level of $\mathrm{K}$ in the NS the potassium content in microgreens was $46 \%$ lower compared with 58.4 and $117 \mathrm{mg} \mathrm{K} \mathrm{L}^{-1}$ (Table 1). Also for magnesium no differences were found between the three $\mathrm{G}$, while 58.4 and $117 \mathrm{mg} \mathrm{K} \mathrm{L}^{-1}$ decreased the magnesium content in the microgreens by $22 \%$ and $47 \%$, respectively, compared with the 0 level of K in the NS. With regards to the calcium, the $\mathrm{CI}$ showed the highest content in the microgreens, while with 0 level of $\mathrm{K}$ in the NS, the calcium content in the microgreens was 50\% higher, compared with ones grown with $117 \mathrm{mg} \mathrm{K} \mathrm{L}^{-1}$ (Table 1). 
In the second experiment, the $\mathrm{K}$ level in the NS did not affect the sodium content in the microgreens, while the LB showed a content that was $57 \%$ lower compared with the CI and CM. No differences in the potassium content were found between the three Gs, while with 0 and $29.1 \mathrm{mg} \mathrm{K} \mathrm{L}^{-1}$, the potassium content in the microgreens was $53 \%$ lower compared with $58.4 \mathrm{mg} \mathrm{K} \mathrm{L}^{-1}$ in the NS (Table 2). No difference was observed in terms of the magnesium (30 mg $100 \mathrm{~g}^{-1} \mathrm{FW}$, on average) and calcium (100 mg $100 \mathrm{~g}^{-1} \mathrm{FW}$, on average) content.

\subsection{Proximate Analysis and Antioxidant Activity}

In the first experiment, no differences were observed in terms of the total lipid $\left(0.37 \mathrm{~g}^{100 \mathrm{~g}^{-1}}\right.$ FW, on average) and protein (1.93 $\mathrm{g} 100 \mathrm{~g}^{-1} \mathrm{FW}$, on average) (Table 3). The K level in the NS did not affect the antioxidant activity in the LB and CM, while for the CI microgreens that were grown with $0 \mathrm{mg} \mathrm{K} \mathrm{L}^{-1}$, an antioxidant activity value of $85 \%$ higher was shown, compared with the microgreens that were grown with $117 \mathrm{mg} \mathrm{K} \mathrm{L}^{-1}$ (Figure 4).

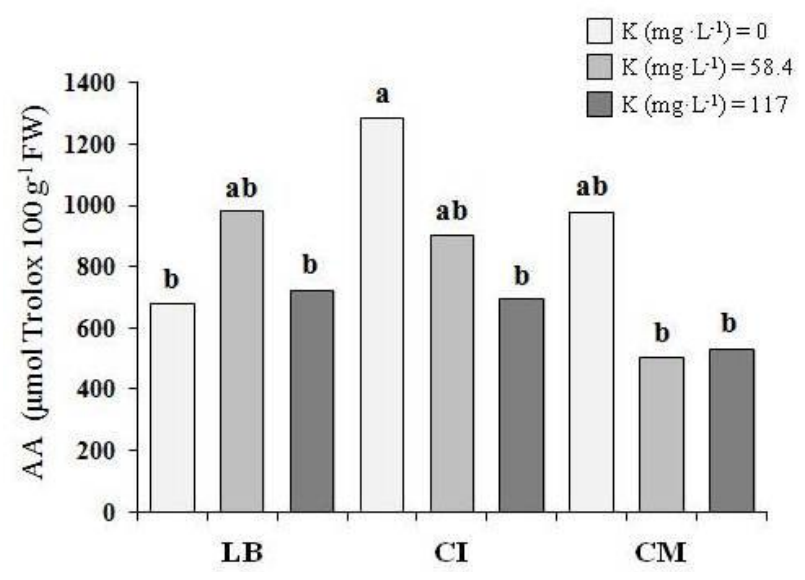

Figure 4. Antioxidant activity (AA) of the three genotypes of microgreens that were grown with thethree potassium levels (first experiment). LB-lettuce 'Bionda da taglio'; CI-chicory 'Italico a foglia rossa'; CM-chicory 'Molfetta'. The same lowercase letters indicate that the mean values are not significantly different $(p=0.05)$.

Table 3. Effects of genotype and potassium on total lipid, protein, total carbohydrate, fiber, ashes, and antioxidant activity of microgreens (first experiment).

\begin{tabular}{|c|c|c|c|c|c|c|}
\hline & Total Lipid & Protein & $\begin{array}{c}\text { Total } \\
\text { Carbohydrate }\end{array}$ & Fiber, Total Dietary & Ashes & Trolox \\
\hline & \multicolumn{5}{|c|}{$\mathrm{g} 100 \mathrm{~g}^{-1} \mathrm{FW}$} & $\mu \mathrm{mol} 100 \mathrm{~g}^{-1} \mathrm{FW}$ \\
\hline \multicolumn{7}{|c|}{ Genotype (G) } \\
\hline LB & 0.40 & 1.75 & $3.47 \mathrm{~b}$ & $0.49 \mathrm{~b}$ & $0.81 \mathrm{~b}$ & $793.2 \mathrm{ab}$ \\
\hline CI & 0.34 & 2.11 & $4.55 \mathrm{a}$ & $0.79 \mathrm{a}$ & $1.04 \mathrm{a}$ & $959.4 \mathrm{a}$ \\
\hline $\mathrm{CM}$ & 0.36 & 1.93 & $3.79 \mathrm{~b}$ & $0.80 \mathrm{a}$ & $0.88 \mathrm{ab}$ & $668.5 \mathrm{~b}$ \\
\hline \multicolumn{7}{|c|}{$\mathbf{K}\left(\mathrm{mg} \mathrm{L}^{-1}\right)$} \\
\hline 0 & 0.42 & 2.17 & 4.86 & 0.82 & 0.88 & 978.9 \\
\hline 58.4 & 0.37 & 1.93 & 3.74 & 0.65 & 0.95 & 794.9 \\
\hline 117 & 0.32 & 1.68 & 3.20 & 0.60 & 0.90 & 647.3 \\
\hline \multicolumn{7}{|c|}{ Significance } \\
\hline G & NS & NS & * & $* * *$ & * & * \\
\hline K & NS & NS & NS & NS & NS & NS \\
\hline $\mathrm{G}^{*} \mathrm{~K}$ & NS & NS & NS & NS & NS & $*$ \\
\hline
\end{tabular}

LB-lettuce 'Bionda da taglio'; CI-chicory 'Italico a costa rossa'; CM-chicory 'Molfetta'. Within the same main effect and for each parameter, the same lowercase letters in the same column indicate that the mean values are not significantly different $(p=0.05)$. A G $\times \mathrm{K}$ significant interaction is reported in Figure 4 . Significance: ${ }^{* *}$ and ${ }^{*}$ are for $p \leq 0.001$ and $p \leq 0.05$, respectively; NS-not significant. 
With regards to the total carbohydrate, the CI showed a content that was $25 \%$ higher when compared with the other genotypes, while the LB showed the lowest fiber content. The ashes were higher in CI compared with the LB, while no differences were observed in comparison with the CM (Table 3).

In the second experiment, no difference was observed in terms of the total lipid, protein, total carbohydrate, and ashes, with average values of $0.29,1.79,3.00$, and $0.77 \mathrm{~g} 100 \mathrm{~g}^{-1} \mathrm{FW}$, respectively (Table 4). The microgreens of the CI showed a fiber content that was $25 \%$ higher and an antioxidant activity that was $66 \%$ higher when compared with the other genotypes (Table 4 ).

Table 4. Effects of genotype and potassium on total lipid, protein, total carbohydrate, fiber, ashes, and antioxidant activity of microgreens (second experiment).

\begin{tabular}{|c|c|c|c|c|c|c|}
\hline & Total Lipid & Protein & Total Carbohydrate & Fiber, Total Dietary & Ashes & Trolox \\
\hline & \multicolumn{5}{|c|}{$\mathrm{g} 100 \mathrm{~g}^{-1} \mathrm{FW}$} & $\mu \mathrm{mol} 100 \mathrm{~g}^{-1} \mathrm{FW}$ \\
\hline \multicolumn{7}{|c|}{ Genotype (G) } \\
\hline LB & 0.32 & 1.87 & 3.09 & $0.64 \mathrm{~b}$ & 0.73 & $457.0 \mathrm{~b}$ \\
\hline CI & 0.26 & 1.89 & 3.26 & $0.80 \mathrm{a}$ & 0.83 & $663.0 \mathrm{a}$ \\
\hline $\mathrm{CM}$ & 0.30 & 1.64 & 2.78 & $0.64 \mathrm{~b}$ & 0.78 & $344.1 \mathrm{~b}$ \\
\hline \multicolumn{7}{|c|}{$\mathbf{K}\left(\mathrm{mg} \mathrm{L}^{-1}\right)$} \\
\hline 0 & 0.30 & 1.80 & 3.28 & 0.69 & 0.69 & 531.5 \\
\hline 29.1 & 0.25 & 1.59 & 2.52 & 0.61 & 0.69 & 500.7 \\
\hline 58.4 & 0.31 & 1.97 & 3.19 & 0.77 & 0.93 & 489.0 \\
\hline \multicolumn{7}{|c|}{ Significance } \\
\hline G & NS & NS & NS & $* *$ & NS & $* *$ \\
\hline K & NS & NS & NS & NS & NS & NS \\
\hline $\mathrm{G}^{*} \mathrm{~K}$ & NS & NS & NS & NS & NS & NS \\
\hline
\end{tabular}

\section{Discussion}

In this study, for the first time, some chicory and lettuce genotypes were grown using a hydroponic system that was used for producing microgreens with low $\mathrm{K}$ content. We used an NS with ion concentrations that were similar to those that were reported by Hoagland [26], but at half strength. Moreover, for the potassium we also reduced the concentration until $0 \mathrm{mg} \mathrm{L}^{-1}$ was reached. We found that, independently of the genotype, in both of the experiments, the K content in the microgreens was successfully reduced by about $50 \%$ using an NS without potassium, with respect to the NS with a $\mathrm{K}$ concentration $\geq 58.4 \mathrm{mg} \mathrm{L}^{-1}$ (Tables 1 and 2). In agreement with Di Gioia et al. [20], it was therefore possible to confirm that the mineral content in microgreens could be strongly determined by the availability of the same minerals in the provided solution. No difference was observed in terms of the shoot height, dry matter, and visual quality (Figure 2). At the same time, by reducing the potassium in the NS, we observed a lower yield, probably as a result of the fact that a potential $\mathrm{K}$ deficiency in plant tissues could negatively affect the stomatal opening, thereby impairing $\mathrm{CO}_{2}$ fixation [27]. Furthermore, when faced with this weakness, it was important to highlight the supply of $\mathrm{K}$ by a serving size of microgreens as well as to evaluate the $\mathrm{K}$ intake for the patients that were affected by chronic kidney disease. In the case of microgreens that were grown without $\mathrm{K}$ or with $29.1 \mathrm{mg} \mathrm{K} \mathrm{L}^{-1}$, a serving size of $100 \mathrm{~g}$ supplied between 103 and $130 \mathrm{mg}$ of $\mathrm{K}$ (Tables 1 and 2), whereas $100 \mathrm{~g}$ of microgreens that were grown using an NS with a K concentration $\geq 58.4 \mathrm{mg} \mathrm{L}^{-1}$ supply between 225 and $250 \mathrm{mg}$ of $\mathrm{K}$ (Tables 1 and 2). Considering that, for the healthy population, the Institute of Medicine of the National Academies [28] had set an intake of limit of $4700 \mathrm{mg} \mathrm{K}$ per day, for the patients that were affected by chronic kidney disease, the intake from food was restricted to $1500 \mathrm{mg}$ per day [7]. It was found that $100 \mathrm{~g}$ of microgreens, grown either without $\mathrm{K}$ or with low levels of $\mathrm{K}$, would provide about $7.7-8.6 \%$ of the $\mathrm{K}$ daily intake that was recommended for the patients that were affected by chronic kidney disease, while $100 \mathrm{~g}$ of the microgreens that were grown using an NS with a $\mathrm{K}$ concentration $\geq 58.4 \mathrm{mg} \mathrm{L}^{-1}$ would provide about $15.8-16.5 \%$ of the K daily intake that was recommended for the patients that were affected by chronic kidney disease. Pinto et al. [29] showed a K content of $365 \mathrm{mg} 100 \mathrm{~g}^{-1} \mathrm{FW}$ 
for microgreens lettuces. Xiao et al. [30] indicated an average K content of $268 \mathrm{mg} 100 \mathrm{~g}^{-1} \mathrm{FW}$ for the microgreens that were obtained by several genotypes of Brassica oleracea L. For the arugula microgreens (Eruca vesicaria [L.] Cav.), some of the authors [20,30] indicated a potassium content between 301 and

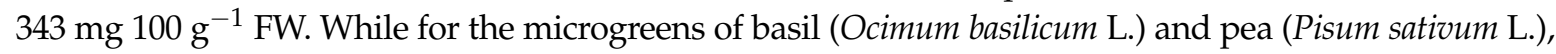
Di Gioia et al. [20] indicated a K content of 294 and $436 \mathrm{mg} 100 \mathrm{~g}^{-1} \mathrm{FW}$, respectively. To the best of our knowledge, the literature lacked information regarding the $\mathrm{K}$ content in microgreens of the chicory genotypes. In addition, the results of the present study suggested a significant reduction of $\mathrm{K}$ in the microgreens that were destined to the patients with impaired kidney function, by reducing the $\mathrm{K}$ concentration in a Hoagland-like NS. It could be also interesting to compare the K content between these microgreens and the same species that were harvested at the regular stage (mature

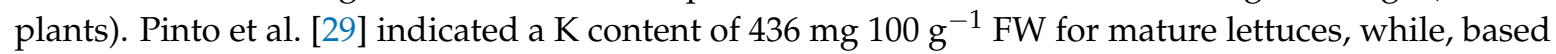
on the average data that were reported from the National Nutrient Database of the United States Department of Agriculture [31], $100 \mathrm{~g}$ of mature leafy chicory supplied about $420 \mathrm{mg} 100 \mathrm{~g}^{-1} \mathrm{FW}$. Thus, it was possible to highlight the very high positive impact of the reduced potassium concentrations in a nutrient solution, in terms of the microgreens production with a low $\mathrm{K}$ content for the patients with impaired kidney function. Moreover, according to the EC Regulation 1924/2006 on nutrition and health claims made about foods [32], the micro chicory and micro lettuce that were obtained in this study could also have been labeled with the nutritional claim 'reduced potassium'. This was because the reduction in their $\mathrm{K}$ content was more than $30 \%$, compared with the average $\mathrm{K}$ content of the same species that were harvested as mature plants. The availability of microgreens with a low potassium content could be exploited for two different objectives, namely: (i) to reduce the potassium intake for the same vegetable serving and (ii) to increase the amount of servings, without excessively increasing the potassium intake. The second objective could have been pursued since the potassium salts in fruits and vegetables contributed to the alkali-producing effects of these foods, also considering that this property was shown, in many recent studies, to have been of benefit in chronic kidney disease patients [8].

When the potassium content was drastically reduced from 117 to $0 \mathrm{mg} \mathrm{K} \mathrm{L}^{-1}$, the average content of the sodium, magnesium, and calcium slightly increased in the microgreens (Table 1). According to some authors $[33,34]$, the increase of these cations could have been a plant's response by alleviating the negative effects of the potassium deficiency in the vegetable tissues. This considered the similar roles in the osmotic adjustment, as well as in the cellular $\mathrm{pH}$ and enzyme activation for both the potassium and magnesium cations [35]. At the same time, it should have also considered the role of sodium in replacing the potassium in both the biochemical and physiological non-specific functions [36]. It was interesting to highlight that, only for the $\mathrm{CI}$ in the first experiment, there was a significant sodium increase in microgreens that was observed, using an NS without potassium (Figure 3). This suggested a possible plant mechanism of $\mathrm{Na}^{+}$exclusion, which depended on the genotype. Furthermore, from a nutritional point of view, the results of the present study showed that $100 \mathrm{~g}$ of the CI that was grown using an NS without K, supplied about $150 \mathrm{mg}$ of sodium. This amount, which represented about $10 \%$ of the daily intake (1.5 g of sodium per day), was recommended by the European Food Safety Authority [4] and could be considered acceptable. In the second experiment, no difference in the sodium, magnesium, and calcium content in the vegetable tissues were observed when varying the $\mathrm{K}$ content in the NS, and also in the case of microgreens that were grown without potassium (Table 2). Therefore, with the exception of the chicory that was cultivated without $\mathrm{K}$ in the first experiment, the average sodium content in the microgreens (Figure 3 and Table 2) was similar, compared to the conventional chicory and lettuce [31]. It was possible that the different climate conditions during the second experiments, especially the higher relative humidity and lower mean temperatures during the last three days before harvesting (Figure 1), would have positively affected the growth and the same mechanisms of osmotic adjustments that had occurred during the first experiment were probably not necessary. Actually, in the second experiment, we found a generally higher yield in comparison with the first experiment at the same level of potassium in the NS (Tables 1 and 2). Therefore, we could 
hypothesize that with the different climate conditions during the second experiment, the other solutes, such as sugars and amino acids, could have contributed to the osmotic adjustments [37].

Regarding the proximate composition in both of the experiments, the K level in the NS did not affect the content of the proteins, lipids, total carbohydrates, and fibers. These results suggested that by using an NS without K or with low potassium concentrations, it was possible to obtain a useful reduction of $\mathrm{K}$ in the microgreens, without negatively affecting an important aspect of the vegetables' nutritional quality, such as the proximate composition. To the best of knowledge, the proximate analysis on the microgreens was carried out for the first time in the present study. Thus, from a nutritional point of view, it could be interesting to compare the proximate composition between the microgreens that were studied in this study, with the same species that were harvested at the regular stage (mature plants). Based on the average data that were reported from the National Nutrient Database of the United States Department of Agriculture [31], $100 \mathrm{~g}$ of chicory greens supplied about $1.7 \mathrm{~g}$ of protein, $0.3 \mathrm{~g}$ of lipids, $4.7 \mathrm{~g}$ of total carbohydrates, and $4.0 \mathrm{~g}$ of fibers. The same serving size of green leafy lettuce supplied about $1.36 \mathrm{~g}$ of proteins, $0.15 \mathrm{~g}$ of lipids, $2.87 \mathrm{~g}$ of total carbohydrates, and $1.3 \mathrm{~g}$ of fibers [31]. For both of the genotypes of chicory that were grown in this study, the content of the protein and lipid in the microgreens (Tables 3 and 4) seemed to be similar in comparison with the mature plants of the same species. At the same time, it was possible to observe a slightly lower content of total carbohydrates and a much lower content of dietary fiber (Tables 3 and 4). For lettuce, the content of the proteins, lipids, and total carbohydrates in the microgreens resulted in being similar in comparison with the mature plants of the same species, while the fiber content results were lower (Tables 3 and 4). These results suggested the possibility of introducing microgreens into the diet of the patients with impaired kidney function that were limiting $\mathrm{K}$ intake and, at the same time, without modifying the intake of the macronutrients, in comparison with the mature plants. Moreover, considering their lower fiber content, the microgreens that were obtained in the present study could have also been proposed in the case of the patients that were affected by some gastrointestinal disorders, such as bowel colon syndrome.

With regards the antioxidant activity, generally higher levels were observed in the first experiment. It was well known that the antioxidant activity in vegetables was as a result of the presence of several phytochemicals. In this context, it was important to underline that light conditions could affect the accumulation of phytochemicals, especially in controlled growth environments [38]. In the soilless production of rocket that was grown under different types of greenhouses, Buttaro et al. [39] reported a lower antioxidant capacity in the plants that were grown with a lower light intensity. Some of the authors $[40,41]$ showed an increase in the antioxidant compounds of microgreens when a supplemental light source was applied for three days before the harvest. In our research, during the last three days of the second experiment, we observed a lower photosynthetically active radiation (PAR) inside the greenhouse, in comparison with the first experiment (Figure 1). Therefore, we could hypothesize that this different light condition in the second experiment might have negatively affected the average antioxidant activity of the microgreens in comparison with the first experiment. In both of the experiments, the CI microgreens generally showed the strongest antioxidant activity (Tables 3 and 4). The observed levels were comparable to those that were reported for the radish microgreens [42]. Generally, the K level in the NS did not affect the antioxidant activity, with the exception of the CI in the first experiment. Actually, when the potassium content in the NS was drastically reduced from 117 to $0 \mathrm{mg} \mathrm{K} \mathrm{L}^{-1}$, the antioxidant activity for the microgreens of this genotype increased (Figure 4). In both of the experiments, it was possible to observe a different antioxidant activity, depending on the genotypes (Tables 3 and 4). In a study that was aimed to evaluate how the potassium content in the NS affected the antioxidant properties in basil (Ocimum basilicum L.), an increase in the antioxidant activity was observed when the $\mathrm{K}$ increased from 1.0 to $2.0 \mathrm{mM} \mathrm{K}$, but lower values were observed at $5.0 \mathrm{mM} \mathrm{K} \mathrm{[43].} \mathrm{Moreover,} \mathrm{these} \mathrm{authors} \mathrm{showed} \mathrm{that} \mathrm{the} \mathrm{antioxidant} \mathrm{capacity} \mathrm{was}$ differently affected by potassium treatment among the three different cultivars that were studied. In agreement with these authors, the results of the present study suggested that the changes of 
the K level in the NS might have significantly affected the antioxidant activity of the microgreens, depending on the genotypes and light conditions.

Finally, from a commercial point of view, it was interesting to highlight the following: (i) currently, microgreens could be considered a successful product in the food market; (ii) the soilless cultivation method that was proposed in this study was very similar to that of the commercial production of microgreens and conventional vegetables; (iii) no additional cost were required for the microgreens production with low potassium content, with respect to the conventional ones.

\section{Conclusions}

Independent of the genotype, we found a useful reduction of potassium in microgreens by reducing the potassium concentration in the nutrient solution, without negatively affecting the proximate composition. Thanks to their distinctive peculiarities, the microgreens that were produced in this study could be labeled with the nutritional claim 'reduced potassium', without the additional costs with respect to the conventional microgreens' production. The availability of the microgreens with a low potassium content could be exploited so as to reduce the potassium intake for the same vegetable serving or to increase the amount of the vegetable serving without excessively increasing the potassium intake for the patients with impaired kidney function. Future research activities could be aimed toward the application of this cultivation method on several other genotypes, in order to obtain a large variety of these special food products. Possible next goals may also be directed towards the assessment of the nutritional and functional changes in the microgreens components during the storage of fresh-cut products with a low potassium content. Other research activities could be aimed toward the assessment of the nutrient compounds' bioaccessibility in microgreens with a low potassium content, using in vitro gastro-intestinal digestion. Finally, animal experiments using chronic renal disease models and / or clinical studies could be carried out for assessing the potential benefits of microgreens with a low potassium content in comparison to the conventional ones for the patients with an impaired kidney function.

Author Contributions: M.R. and P.S.: Substantial contributions to the conception or design of the work; agreement to be accountable for all aspects of the work, in ensuring that the questions related to the accuracy or integrity of any part of the workwere appropriately investigated and resolved. M.R.: Drafting the work. P.S.: Analysis of data. V.M.P. and M.C.: carried out proximate analyses. B.L.: Carried out biometric and yield measures. V.M.P.: Revised the article critically and coordinated the proximate analyses. All of the authors participated in the interpretation of the data and helped to draft the manuscript. All of the authors read and approved the final manuscript. M.R. and P.S. were responsible for the final approval of the version that is to be published.

Funding: This research was funded by Fondazione Puglia under the Program 'Ricerca Scientifica e Tecnologica -Bando Ricercatori $2015^{\prime}$, project "Produzione di micro-ortaggi con basso contenuto di potassio per pazienti affetti da insufficienza renale"

Acknowledgments: The authors thank Gerolmina Florio and Vito Rocco De Michele for their technical assistance. The authors dedicate to Nino, who inspired this research without being able to reap the benefits.

Conflicts of Interest: The authors declare no conflict of interest.

\section{References}

1. Choi, H.Y.; Ha, S.K. Potassium Balances in Maintenance Hemodialysis. Electrol. Blood Press. 2013, 11, 9. [CrossRef] [PubMed]

2. World Health Organization (WHO). Guideline: Potassium Intake for Adults and Children; WHO: Geneva, Switzerland, 2012; pp. 1-42.

3. European Food Safety Authority. Tolerable Upper Intake Levels for Vitamins and Minerals; European Food Safety Authority: Parma, Italy, 2006; ISBN 9291990140.

4. Ikegami, F.; Wang, Y.; Kaneko, M.; Sumino, M.; Tsukagoshi, S. Human health sciences-From cultivation to utilization of medicinal plants. Open J. Prev. Med. 2012, 2, 214-224. [CrossRef]

5. Fresenius Medical Care. Annual Report 2013; Fresenius Medical Care: Bad Homburg vor der Höhe, Germany, 2013. 
6. Committee for Revision of Diet Therapy. Guideline Dietary Recommendations for Chronic Kidney Disease. Nihon Jinzo Gakkai Shi 2007, 49, 871-878.

7. Putcha, N.; Allon, M. Management of Hyperkalemia in Dialysis Patients. Semin. Dial. 2007, 20, 431-439. [CrossRef] [PubMed]

8. St-Jules, D.E.; Goldfarb, D.S.; Sevick, M.A. Nutrient Non-equivalence: Does Restricting High-Potassium Plant Foods Help to Prevent Hyperkalemia in Hemodialysis Patients? J. Ren. Nutr. 2016, 26, 282-287. [CrossRef] [PubMed]

9. Weiner, I.D.; Wingo, C.S. Hyperkalemia: A Potential Silent Killer. J. Am. Soc. Nephrol. 1998, 9, $1535-1543$. [PubMed]

10. Renna, M.; Cocozza, C.; Gonnella, M.; Abdelrahman, H.; Santamaria, P. Elemental characterization of wild edible plants from countryside and urban areas. Food Chem. 2015, 177, 29-36. [CrossRef] [PubMed]

11. Burrowes, J.D.; Ramer, N.J. Changes in potassium content of different potato varieties after cooking. J. Ren. Nutr. 2008, 18, 530-534. [CrossRef] [PubMed]

12. Kawashima, L.M.; Valente Soares, L.M. Mineral profile of raw and cooked leafy vegetables consumed in Southern Brazil. J. Food Compos. Anal. 2003, 16, 605-611. [CrossRef]

13. Mazzeo, T.; N’Dri, D.; Chiavaro, E.; Visconti, A.; Fogliano, V.; Pellegrini, N. Effect of two cooking procedures on phytochemical compounds, total antioxidant capacity and colour of selected frozen vegetables. Food Chem. 2011, 128, 627-633. [CrossRef]

14. Martínez-Hernández, G.B.; Artés-Hernández, F.; Colares-Souza, F.; Gómez, P.A.; García-Gómez, P.; Artés, F. Innovative Cooking Techniques for Improving the Overall Quality of a Kailan-Hybrid Broccoli. Food Bioprocess Technol. 2013, 6, 2135-2149. [CrossRef]

15. Ogawa, A.; Egughi, T.; Toyofoku, K. Cultivation Methods for Leafy Vegetables and Tomatoes with Low Potassium Content for Dialysis Patients. Environ. Control Biol. 2012, 50, 407-414. [CrossRef]

16. Asao, T.; Asaduzzaman, M.; Mondal, M.F.; Tokura, M.; Adachi, F.; Ueno, M.; Kawaguchi, M.; Yano, S.; Ban, T. Impact of reduced potassium nitrate concentrations in nutrient solution on the growth, yield and fruit quality of melon in hydroponics. Sci. Hortic. (Amst.) 2013, 164, 221-231. [CrossRef]

17. Tsukagoshi, S.; Hamano, E.; Hohjo, M.; Ikegami, F. Hydroponic Production of Low-Potassium Tomato Fruit for Dialysis Patients. Int. J. Veg. Sci. 2016, 22, 451-460. [CrossRef]

18. Kyriacou, M.C.; Rouphael, Y.; Di Gioia, F.; Kyratzis, A.; Serio, F.; Renna, M.; De Pascale, S.; Santamaria, P. Micro-scale vegetable production and the rise of microgreens. Trends Food Sci. Technol. 2016, 57, 103-115. [CrossRef]

19. Renna, M.; Di Gioia, F.; Leoni, B.; Mininni, C.; Santamaria, P. Culinary Assessment of Self-Produced Microgreens as Basic Ingredients in Sweet and Savory Dishes. J. Culin. Sci. Technol. 2017, 15, 126-142. [CrossRef]

20. Di Gioia, F.; Renna, M.; Santamaria, P. Sprouts, Microgreens and “Baby Leaf" Vegetables. In Minimally Processed Refrigerated Fruits and Vegetables; Springer: Boston, MA, USA, 2017; pp. 403-432, ISBN 978-1-4939-7016-2.

21. Mir, S.A.; Shah, M.A.; Mir, M.M. Microgreens: Production, shelf life, and bioactive components. Crit. Rev. Food Sci. Nutr. 2017, 57, 2730-2736. [CrossRef] [PubMed]

22. Kyriacou, M.C.; De Pascale, S.; Kyratzis, A.; Rouphael, Y. Microgreens as a Component of Space Life Support Systems: A Cornucopia of Functional Food. Front. Plant Sci. 2017, 8, 1587. [CrossRef] [PubMed]

23. AOAC. Official Methods of Analysis of AOAC International, 16th ed.; AOAC International: Rockville, MD, USA, 1995; Volume 1.

24. Difonzo, G.; Russo, A.; Trani, A.; Paradiso, V.M.; Ranieri, M.; Pasqualone, A.; Summo, C.; Tamma, G.; Silletti, R.; Caponio, F. Green extracts from Coratina olive cultivar leaves: Antioxidant characterization and biological activity. J. Funct. Foods 2017, 31, 63-70. [CrossRef]

25. D'Imperio, M.; Renna, M.; Cardinali, A.; Buttaro, D.; Santamaria, P.; Serio, F. Silicon biofortification of leafy vegetables and its bioaccessibility in the edible parts. J. Sci. Food Agric. 2016, 96, 751-756. [CrossRef] [PubMed]

26. Hoagland, D.R.; Arnon, D.I. The Water-Culture Method for Growing Plants without Soil, 2nd ed.; California Agricultural Experiment Station: Davis, CA, USA, 1950; Volume 347.

27. Cakmak, I. The role of potassium in alleviating detrimental effects of abiotic stresses in plants. J. Plant Nutr. Soil Sci. 2005, 168, 521-530. [CrossRef] 
28. Food and Nutritional Board. Dietary Reference Intakes for Water, Potassium, Sodium, Chloride, and Sulfate; National Academies Press: Washington, DC, USA, 2005; ISBN 978-0-309-09169-5.

29. Pinto, E.; Almeida, A.A.; Aguiar, A.A.; Ferreira, I.M.P. Comparison between the mineral profile and nitrate content of microgreens and mature lettuces. J. Food Compos. Anal. 2015, 37, 38-43. [CrossRef]

30. Xiao, Z.; Codling, E.E.; Luo, Y.; Nou, X.; Lester, G.E.; Wang, Q. Microgreens of Brassicaceae: Mineral composition and content of 30 varieties. J. Food Compos. Anal. 2016, 49, 87-93. [CrossRef]

31. United States Department of Agriculture National Nutrient Database for Standard Reference Release 28. Available online: https://ndb.nal.usda.gov/ndb/search/list?SYNCHRONIZER_TOKEN=c42319cd7b79-4908-b3e8-5bb7ca42944c\&SYNCHRONIZER_URI=\%2Fndb\%2Fsearch\%2Flist\&qt=\&ds=Standard+ Reference\&qlookup=\&manu= (accessed on 10 April 2018).

32. European Parliament and The Council of the European Union. REGULATION (EC) No 1924/2006 of the European Parliament and of the Council of 20 December 2006 on nutrition and health claims made on foods. Off. J. Eur. Union 2006, 49, 9-25.

33. Diem, B.; Godbold, D.L. Potassium, calcium and magnesium antagonism in clones of Populus trichocarpa. Plant Soil 1993, 155-156, 411-414. [CrossRef]

34. Pujos, A.; Morard, P. Effects of potassium deficiency on tomato growth and mineral nutrition at the early production stage. Plant Soil 1997, 189, 189-196. [CrossRef]

35. Marschner, H. Mineral Nutrition of Higher Plants; Academic Press: Cambridge, MA, USA, 1995; ISBN 9780080571874.

36. Flowers, T.J.; Lauchli, A. Sodium versus potassium: Substitution and compartmentation. Encycl. Plant Physiol. 1983, 15, 651-681.

37. Ogawa, A.; Yamauchi, A. Root Osmotic Adjustment under Osmotic Stress in Maize Seedlings. 2. Mode of Accumulation of Several Solutes for Osmotic Adjustment in the Root. Plant Prod. Sci. 2006, 9, 39-46. [CrossRef]

38. Delian, E.; Chira, A.; Bădulescu, L.; Chira, L. Scientific Papers Series B Horticulture; University of Agronomic Sciences and Veterinary Medicine: București, Romania, 2012.

39. Buttaro, D.; Renna, M.; Gerardi, C.; Blando, F.; Santamaria, P.; Serio, F. Soilless production of wild rocket as affected by greenhouse coverage with photovoltaic modules. Acta Sci. Pol. Cultus 2016, 15, 129-142.

40. Samuolienè, G.; Brazaitytè, A.; Sirtautas, R.; Sakalauskienè, S.; Jankauskienè, J.; Duchovskis, P.; Novičkovas, A. The Impact of supplementary short-term red led lighting on the antioxidant properties of microgreens. Acta Hortic. 2012, 649-656. [CrossRef]

41. Brazaitytè, A.; Jankauskienè, J.; Novičkovas, A. The effects of supplementary short-term red LEDs lighting on nutritional quality of Perilla frutescens L. Rural Dev. 2013, 2013, 54-58.

42. Xiao, Z.; Lester, G.E.; Luo, Y.; Xie, Z.; Yu, L.; Wang, Q. Effect of light exposure on sensorial quality, concentrations of bioactive compounds and antioxidant capacity of radish microgreens during low temperature storage. Food Chem. 2014, 151, 472-479. [CrossRef] [PubMed]

43. Nguyen, P.M.; Kwee, E.M.; Niemeyer, E.D. Potassium rate alters the antioxidant capacity and phenolic concentration of basil (Ocimum basilicum L.) leaves. Food Chem. 2010, 123, 1235-1241. [CrossRef]

(C) 2018 by the authors. Licensee MDPI, Basel, Switzerland. This article is an open access article distributed under the terms and conditions of the Creative Commons Attribution (CC BY) license (http://creativecommons.org/licenses/by/4.0/). 